\title{
Vitamin D status in patients with nontraumatic transient loss of consciousness (literature review)
}

\author{
For citation: Bol', sustavy, pozvonočnik. 2019;9(3):178-183. doi: 10.22141/2224-1507.9.3.2019.178642
}

\begin{abstract}
The article presents an analysis of the recent scientific findings on vitamin D status in patients with different etiopathogenetic varieties of nontraumatic transient loss of consciousness. The results of recent researches suggest that vitamin D may play an indirect and, in some cases, direct role in the pathogenesis of nontraumatic transient loss of consciousness. Data on the cause-effect relationship between a low vitamin $D$ status and syncope are mixed, controversial and ambiguous, which is largely due to the use of different doses of vitamin $D$, its initial concentration, duration of therapy, genetic differences in the vitamin D receptors, different age groups, physical parameters of the surveyed, medications, peculiarities of nutrition with special supplements, differences in physical activity, peculiarities of the climate and season, and others. Until now there is no convincing evidence of the benefits of using vitamin $D$ in the treatment and prevention of syncope. Most studies are observational and relate mainly to adult populations. Therefore, randomized controlled studies focused on children may be a promising field of research.
\end{abstract}

Keywords: nontraumatic transient loss of consciousness; reflex syncope; orthostatic hypotension; cardiogenic syncope; epilepsy; psychogenic syncope; vitamin D; review

\section{Introduction}

Nowadays it is evident that Vitamin D plays an essential role in the regulation of Calcium $(\mathrm{Ca})$ and Phosphorus $(\mathrm{P})$ homeostasis as well as in the processes related to bone mineralization and bone mass accumulation. Besides the historically-recorded skeletal functions, it has lately been revealed that Vitamin D is directly or tangentially involved in 1250 genes' regulation, thus performing the extra-skeletal functions [1]. For this reason, Vitamin D's deficiency may influence not only the locomotor apparatus, but a potentially wide scope of acute and chronic conditions, namely in children. There are scientific proofs that Vitamin D's deficiency is related to infectious diseases, bronchial asthma, atopic dermatitis, allergic conditions, diabetes mellitus Type 1, inflammatory bowel conditions, celiac disease, metabolic syndrome and obesity, autism, depression and many others [2-7].

Most scientists agree that Vitamin D supplementation has a positive effect on human health. However, there is no conclusive evidence about its deficiency's promoting disorders. For this reason, a primary hypothesis of reverse causation is widely accepted and supported by a systemic meta-analysis and randomized controlled trials $[8,9]$. Ongoing studies point out potential benefits and minimal risks of Vitamin D supplementation, maintaining optimal and safe 25-hydroxy Vitamin D concentration in those groups unable of synthesizing enough Vitamin D in their skins [10].

Despite an extensive evidence base of Vitamin D's deficiency and insufficiency studies in connection to numerous children's diseases, many aspects of this connection are left unclear and disputable. In the recent years, there are many reports on Vitamin D deficiency's implication in children's syncope pathogenesis [11-13]. In 2018, the European Society of Cardiology (ESC) published the clinical Guidelines for the diagnosis and management of syncope, in which all the nontraumatic transient losses of consciousness were classified according to four principal groups: syncope (reflex, orthostatic hypotension, cardiogenic), epileptic seizures, psychogenic (psychogenic pseudosyncope (PPS), psychogenic non-epileptic seizures (PNES) and some rare diseases

C) 2019. The Authors. This is an open access article under the terms of the Creative Commons Attribution 4.0 International License, CC BY, which allows others to freely distribute the published article, with the obligatory reference to the authors of original works and original publication in this journal.

Для кореспонденції: Боярчук Оксана Романівна, доктор медичних наук, професор кафедри дитячих хвороб з дитячою хірургією, ДВНЗ «Тернопільський державний медичний університет імені I.Я. Горбачевського», Майдан Волі, 1, м. Тернопіль, 46001, Україна; e-mail: boyarchuk@tdmu.edu.ua, конт. тел.: +38 (068) 621-82-48

For correspondence: Oksana Boyarchuk, MD, PhD, Head of Department of pediatric diseases and pediatric surgery, State Institution of Higher Education "I. Horbachevsky Ternopil National Medical University", Maidan Voli, 1, Ternopil, 46001, Ukraine; e-mail: boyarchuk@tdmu.edu.ua; phone: +38 (068) 621-82-48

Full list of author information is available at the end of the article. 
[14]. The aim of the present study is to analyze the recent findings on Vitamin D status in patients with various etiopathogenetic varieties of nontraumatic transient losses of consciousness.

\section{Reflex vasovagal syncope}

Autonomic nervous system dysfunction affects Calcium turnover-participating genes' expression both before and after nervous cell differentiation, which gives rise to sympathetic and parasympathetic neurons. Autonomic dysfunction in children and adolescents has heterogenic clinical manifestations due to an imbalance of sympathetic and parasympathetic regulation. It has numerous symptoms, including headaches, dizziness with orthostatic intolerance $(\mathrm{OI})$, accelerated heart rate, gastrointestinal dysfunctions, generalized muscle pain and a low tolerance to physical strain [15].

Vitamin D plays a pivotal role in autonomic homeostasis maintenance and may function as a central neuroactive substance. Activated 1.25-dihydroxyvitamin D is able to coordinate additional molecular mechanisms, namely informing about inflammation and biosynthesis of neuromediators in those sites of central nervous system that regulate cardiovascular activities. It's worthy of mentioning that Calcitriol penetrates the blood-brain barrier (BBB) and binds itself to Vitamin D receptors located in the central nervous system. For instance, mesencephalon and fornicolumn where a number of autonomic nervous neurons are located have a significantly high concentration of Vitamin $\mathrm{D}$ receptors, proving a non-Calcium-moderated role of Vitamin D in autonomic nervous system regulation [16].

Studies by Santillan et al. [17] demonstrate that -adrenergic signal transduction in chicks' myocardial cells increases if the cells are put into the 1.25-dihydroxicholecalciferol medium. Their findings prove that the principal cardiovascular function may be partially attributed to Vitamin D, as arrhythmic signals are perceived not only by the central nervous system, but by the heart as well [17].

Postural orthostatic tachycardia is a prevalent form of autonomic deregulation characterized by an excessive tachycardia after a sudden body rising into an upright position. It may be associated with a pronounced fatigue, headache, accelerated heart rate, sleep disorder, nausea, dizziness and fainting. A study shows that patients with postural orthostatic tachycardia have a 25-hydroxy Vitamin D deficiency in $51 \%$ of cases, and insufficiency - in $56 \%$ [18].

A clinical case of an adult patient diagnosed with postural orthostatic tachycardia according to the tilt test reveals 1.25-dihydroxicholecalciferol's deficiency. A further 5-month-long Calcitriol therapy resulted in an improved orthostatic intolerance and heart rate normalization [19]. Studies of serum Vitamin D's connection with myocardial function of 84 healthy individuals show a weak systolic and diastolic myocardial dysfunction in
Saudi Arabian adolescents with a low Vitamin D's concentration [20].

\section{Orthostatic hypotension syncope}

A low Vitamin D's concentration is associated with an increased risk of orthostatic hypotension. Vitamin D's association with orthostatic hypotension was proved by a meta-analysis of 5 cross-over studies involving 3646 subjects (1270 having hypovitaminosis and 2376 - a normal Vitamin D's concentration in blood serum). In a group of patients with Vitamin D hypovitaminosis orthostatic hypotension was more prevalent than in the healthy population. Furthermore, orthostatic hypotension patients had a significantly lower Vitamin D level in blood serum [21].

In another study, 329 elderly women had a deficient 25-hydroxy Vitamin D associated with orthostatic hypotension due to a decreased diastolic blood pressure with a sudden body's rising into an upright position [22]. Furthermore, in a randomized controlled trial it was proved that a continuous 12-month taking high doses of Vitamin $\mathrm{D}_{3}$ does not affect orthostatic hypotension in elderly patients with an isolated systolic hypertension [23].

There are only few reports on a deficient 25-hydroxy Vitamin D prevalence in children and adolescents with syncope and orthostatic hypotension in the contemporary medical reference sources. In one such study, a group of adolescents with orthostatic intolerance and fainting had a depreciated autonomic function, and excessive catecholamine and vasopressin release during the tilt test [24].

At present, syncope's potential mechanisms of development along with orthostatic failure are not yet entirely clear. Vitamin D may play an intermediary role in an orthostatic hypotension's genesis. This hypothesis is supported by Vitamin D's influence at the systolic and diastolic pressure level [25, 26]. Furthermore, Vitamin $\mathrm{D}$ receptors are located in the vascular smooth muscles, endothelial and cardiac tissues, proving that Vitamin D may influence vasomotor and cardiac response while orthostasis [27].

\section{Cardiogenic causes of syncopal conditions}

Based on the recent experimental and clinical date, the modern medicine points out several mechanisms explaining a possible association between the Vitamin D deficiency and cardiovascular conditions. The model mice lacking Vitamin D receptors had an increased ventricle mass, higher values of atrial natriuretic peptides, disorder of metalloproteinase and fibroblast homeostasis, resulting in ventricle dilatation and disorder of electromechanical connections in cardiomyocytes [28]. O'Connell et al. demonstrated that Calcitriol increases cardiomyocyte protein levels and cellular sizes and assumed that it induces their hypertrophy. S-Phase cell cycle arrest is a mechanism through which 1.25-dihy- 
droxycholecalciferol regulates cardiomyocyte proliferation [29].

One of the cardioprotecting Vitamin D effects is a reduced myocardial hypertrophy mediator expression, namely atrial natriuretic peptide and growth factors stimulating cellular proliferation [30]. A significant discrepancy among Vitamin D level, interventricular septum thickness and left ventricle mass index was revealed after correctional Vitamin D therapy calibrated according to the age, blood pressure rate and serum 25-hydroxy Vitamin D level in a massive retrospective study informing about Vitamin D's role in a ventricular remodeling [31]. Calcium also takes part in a cellular proliferation and activates proteinase, inducing myocardial hypertrophy. Calcium levels rise after Vitamin D taking, leading, on its own, to myocardial hypertrophy, cardiomyocyte apoptosis and heart arrhythmia [32]. Recent findings showing Vitamin D's influence on the left ventricle hypertrophy are not conclusive and representative of its role from the favorable to adverse effect spectrum [33].

But a few studies report on a connection between Vitamin D deficiency and atrial fibrillation [34, 35]. Serum 25-hydroxy Vitamin D level correlated with left atrial diameter, C-reactive protein and pulmonary systolic pressure, to a significant extent being associated with atrial fibrillation in patients with a nonvalvular persistent atrial fibrillation [35].

Direct electromechanical Vitamin D effects on a left atrium were recorded by Hanafy et al., allowing them to prevent and treat atrial fibrillation [36]. However, Rienstra et al., having examined 2930 Framingham Heart study recruits during a 9,9-year period did not find any connection between Vitamin D status and atrial fibrillations. The researchers clam that Vitamin D deficiency does not promote atrial fibrillations [37]. In a recent study of 328 adults, it was shown that Vitamin D prevents post-operative atrial fibrillations only in the patients with deficiency and does not influence post-operative atrial fibrillations in those with insufficiency [38].

Nalbant et al. demonstrated that the heart rate of patients with a low cardiovascular risk and Vitamin D deficiency did not change to a significant extent, according to the results of a 24-hour cardiac electric activity monitoring [39]. There are only a few reports on Vitamin D deficiency and hypocalcemia's role in a prolonged Q-T interval syndrome and supraventricular tachycardia in children [40, 41]. Unfortunately, at the moment, there are no studies on Vitamin D's role in such cardiogenic syncopal conditions, as bifascicular block, intraventricular conduction defect with QRS duration of $\geq 0,12 \mathrm{sec}$, atrioventricular block of II and III degree, inadequate sinus bradycardia, ventricular tachycardia, early ventricular repolarization, ventricular pre-excitation syndrome, Brugada pattern.

It is yet unclear if a connection between a low Vitamin D level and arrhythmia is direct or tangential. It is probable that some unknown factors and endocrine mecha- nism associations affect Vitamin D metabolism [42]. This assumption proves the importance of further studies in this field.

\section{Epileptic seizures}

In children suffering from epilepsy, reduced blood levels of Vitamin D are associated with a tendency of increasing frequency and duration of seizures. Large-scale epidemiological studies report significant seasonal variations in seizure frequency, with the lowest rate observed in the summer and the highest in winter. It is attributed to a low level of 25-hydroxy Vitamin D at the same period [43].

There is a range of studies focused on the possible Vitamin D deficiency's side effects on the epilepsy's etiopathogenesis [44]. One of the possibilities is a direct Vitamin D's influence on the brain, resulting in the reduced neuronal sensitivity and seizure frequency. Vitamin D may affect the seizures by maintaining the neuromediator genes' expression as they take part in the neurotransmission. Furthermore, Vitamin D, being a neurosteroidal agent, may directly interact with $\mathrm{GAB}_{\mathrm{A}} \mathrm{A}$ brain receptors $\left(\mathrm{GABA}_{\mathrm{A}} \mathrm{R}\right)$ [45].

Starting from 1960s, numerous data prove that anticonvulsants have a negative effect on bone turnover and lead to an increased risk of fractures. This observation incited many studies of anticonvulsants' effect and Vitamin D metabolism. Cohort studies demonstrate that anticonvulsant enzyme inducer reduces the level of 25-hydroxy Vitamin D compared with non- enzyme inducers, provoking Vitamin D deficiency in epileptic patients [46-48]. Although there are inconsistencies as to how the anticonvulsants provoke Vitamin D deficiency, they may be attributed to study design discrepancies, geographical location or nutritional habits of the studied groups [49].

There are 2 pilot studies of Vitamin D's efficacy against epilepsy of patients with Vitamin D deficiency. This therapy reduced the $30 \%$ reduction in seizure frequency among the main group as compared to the controls [50, 51]. At present, there is only one randomized controlled trial of various Vitamin D doses' efficacy against the children's epilepsy. It involved 78 children aged 10-18 years on a long-term anticonvulsant therapy. Patients received Vitamin $\mathrm{D}_{3}$ in low (400 IUs / day) or high (2000 IUs / day) doses for 1 year. The study's findings show the bone mineral density improved irrespective of the initial Vitamin D level, and its mean annual therapeutic dose. However, they did not inform about this therapy's efficacy against the seizure frequency [52].

Despite the few findings of the studies recommending global screening and Vitamin D therapy to the patients suffering from its deficiency or insufficiency, there are enough references supporting Vitamin D supplementation for children with epilepsy [53]. According to these, guidelines on the necessity of Vitamin D and Calcium 
supplementation for every epileptic child treated with anticonvulsants for 2 years or longer [54, 55].

The international medical literature does not report any studies of Vitamin D status in patients with psychogenic pseudosyncope and psychogenic non-epileptic seizures. Taking into account the recent findings on Vitamin D deficiency and its association with mental diseases [56], this field is very promising and undoubtedly opening new vistas of potential effects on human health.

In conclusion, the recent studies allow us to claim that Vitamin D may have a tangential, or in some cases, direct influence on the nontraumatic transient losses of consciousness and their pathogenesis. The data on the cause-effect association between the Vitamin D status and syncope conditions are mixed, inconclusive and contradictory, mainly due to various doses used, its initial concentration, therapy's duration, genetic differences of Vitamin D receptors, age, physical parameters, medication, nutritional habits and supplementation, physical activity, climatic and seasonal differences. At present, there are no strong arguments in favor of Vitamin D as a means of prevention and treatment of syncope. Most studies are only observational and involve, primarily, adult population groups. In this light, we consider randomized controlled studies focused on children especially promising.

Conflicts of interests. Authors declare the absence of any conflicts of interests and their own financial interest that might be construed to influence the results or interpretation of their manuscript.

\section{References}

1. Saggese G, Vierucci F, Prodam F, et al. Vitamin D in pediatric age: consensus of the Italian Pediatric Society and the Italian Society of Preventive and Social Pediatrics, jointly with the Italian Federation of Pediatricians. Ital J Pediatr. 2018;44(1):51. https://doi.org/10.1186/s13052-018-0488-7.

2. Esposito S, Lelii M. Vitamin D and respiratory tract infections in childhood. BMC Infect Dis. 2015 Oct 28;15:487. https:// doi.org/10.1186/s12879-015-1196-1.

3. Muehleisen B, Gallo RL. Vitamin D in allergic disease: shedding light on a complex problem. J Allergy Clin Immunol. 2013 Feb;131(2):324-9. https://doi.org/10.1016/j.jaci.2012.12.1562.

4. Cadario F, Prodam F, Savastio S, et al. Vitamin D status and type 1 diabetes in children: evaluation according to latitude and skin color. Minerva Pediatr. 2015 Jun;67(3):263-7.

5. Erdem T, Ferat Ç, Nurdan YA, et al. Vitamin and mineral deficiency in children newly diagnosed with celiac disease. Turk J Med Sci. 2015;45(4):833-6.

6. Jamka M, Woźniewicz M, Walkowiak J, Bogdański P, Jeszka J, Stelmach-Mardas M. The effect of vitamin D supplementation on selected inflammatory biomarkers in obese and overweight subjects: a systematic review with meta-analysis. Eur J Nutr. 2016 Sep;55(6):2163-76. https://doi.org/10.1007/s00394015-1089-5.

7. Saad K., Abdel-Rahman A.A., Elserogy Y.M., et al. Vitamin D status in autism spectrum disorders and the efficacy of vitamin D supplementation in autistic children. Nutr Neurosci. 2016 Oct;19(8):346-351. https://doi.org/10.1179/147683051 5Y.0000000019.

8. Autier P, Boniol M, Pizot C, Mullie P. Vitamin D status and ill health: a systematic review. Lancet Diabetes Endocrinol. 2014 Jan;2(1):76-89. https://doi.org/10.1016/S2213-8587(13)701657.

9. Autier P, Mullie P, Macacu A, et al. Effect of vitamin D supplementation on non-skeletal disorders: a systematic review of meta-analyses and randomised trials. Lancet Diabetes Endocrinol. 2017 Dec;5(12):986-1004. https://doi.org/10.1016/S22138587(17)30357-1.

10. Rusinska A, Płudowski P, Walczak M, et al. Vitamin D Supplementation Guidelines for General Population and Groups at Risk of Vitamin D Deficiency in Poland. Bol', sustavy, pozvonočnik. 2019;9(1):2-27. https://doi.org/10.22141/22241507.9.1.2019.163055. (in Ukrainian).

11. Butler IJ, Lankford JE, Hashmi SS, Numan MT. Biogenic amine metabolism in juvenile neurocardiogenic syncope with dysautonomia. Ann Clin Transl Neurol. 2014 Apr;1(4):2517. https://doi.org/10.1002/acn3.49.

12. Ghaznain M, Donnelly TM, Halpenny L. Tilt Table Test Outcome in the Diagnosis and Prevalence of Syncope in Patients with Vitamin D and Vitamin B12 Deficiency. Age and Ageing. 2017 Sep;46(Suppl 3):iii13-iii59. https://doi.org/10.1093/ageing/ afx144.60.

13. Arici B, Maeder M, Schuetz P, Muelle B, Albrich WC. Potential Role of Biomarkers in the Management of Syncope. International Journal of Clinical Medicine. 2012;3(7A):744-750. http://dx.doi.org/10.4236/ijcm.2012.37A131.

14. Brignole M, Moya A, de Lange FJ, et al. 2018 ESC Guidelines for the diagnosis and management of syncope. Eur Heart J. 2018 Jun 1;39(21):1883-1948. https://doi.org/10.1093/eurheartj/ ehy037.

15. Wadhwania R. Is Vitamin D Deficiency Implicated in Autonomic Dysfunction? J Pediatr Neurosci. 2017 AprJun;12(2):119-123. https://doi.org/10.4103/jpn.JPN_1_17.

16. DeLuca GC, Kimball SM, Kolasinski J, Ramagopalan SV, Ebers GC. Review: The role of vitamin D in nervous system health and disease. Neuropathol Appl Neurobiol. 2013 Aug;39(5):45884. https://doi.org/10.1111/nan.12020.

17. Santillan GE, Vazquez G, Boland R. Activation of a badrenergic-sensitive signal transduction pathway by the secosteroid hormone 1,25-oh2 vitamin D3 in chick heart. J Mol Cell Cardiol. 1999 May;31(5):1095-104. https://doi.org/10.1006/ jmcc.1999.0942.

18. Ashangari C, Suleman A. Vitamin D Deficiency Study in Postural Orthostatic Tachycardia Syndrome. Circulation: Cardiovascular Quality and Outcomes. 2015;8(Suppl 2):A121.

19. Chaudhari SA, Sacerdote A, Bahtiyar G. 1-a hydroxylation defect in postural orthostatic tachycardia syndrome: Remission with calcitriol supplementation. BMJ Case Rep. 2012 Aug 13;2012. pii: bcr0220125730. https://doi.org/10.1136/ bcr.02.2012.5730.

20. Matter M, El-Sherbiny E, Elmougy A, Abass M, Aldossary S, Ali WA. Myocardial function in Saudi adolescents with Vitamin D deficiency: Tissue Doppler imaging study. J Saudi Heart Assoc. 2016 Jan;28(1):22-30. https://doi.org/10.1016/j. jsha.2015.06.006. 
21. Ometto F, Stubbs B, Annweiler C, et al. Hypovitaminosis D and orthostatic hypotension: A systematic review and meta-analysis. J Hypertens. 2016 Jun;34(6):1036-43. https://doi. org/10.1097/HJH.0000000000000907.

22. Annweiler C, Schott AM, Rolland Y, Beauchet O. Vitamin D deficiency is associated with orthostatic hypotension in oldestold women. J Intern Med. 2014 Sep;276(3):285-95. https://doi. org/10.1111/joim.12201.

23. Witham MD, Price RJ, Struthers AD, et al. Effect of vitamin D supplementation on orthostatic hypotension: data from the vitamin D in isolated systolic hypertension randomized controlled trial. J Hypertens. 2014 Aug;32(8):1693-9; discussion 1699. https://doi.org/10.1097/HJH.0000000000000223.

24. Shaltout HA. Abstract P396: Vitamin D Supplementation Improves Cardiovascular Response to Head Up Tilt in Adolescents Suffering from Syncope. Hypertension. 2018 Sep;72(Suppl 1):AP396. https://doi.org/10.1161/hyp.72.suppl_1.P396.

25. Nigwekar SU, Thadhani R. Vitamin D receptor activation: Cardiovascular and renal implications. Kidney Int Suppl (2011). 2013 Dec;3(5):427-430. https://doi.org/10.1038/kisup.2013.89.

26. McCarroll KG, Robinson DJ, Coughlan A, et al. Vitamin D and orthostatic hypotension. Age and Ageing. 2012;41(6):810813. https://doi.org/10.1093/ageing/afs088.

27. Holick MF. Vitamin D deficiency. N Engl J Med. 2007 Jul 19;357(3):266-81. https://doi.org/10.1056/NEJMra070553.

28. Al Mheid I, Patel RS, Tangpricha V, Quyyumi AA. Vitamin D and cardiovascular disease: is the evidence solid? Eur Heart J. 2013 Dec;34(48):3691-8. https://doi.org/10.1093/eurheartj/eht166.

29. O'Connell TD, Berry JE, Jarvis AK, Somerman MJ, Simpson RU. 1,25-Dihydroxyvitamin D3 regulation of cardiac myocyte proliferation and hypertrophy. Am J Physiol. 1997 Apr;272(4 Pt 2):H1751-8. https://doi.org/10.1152/ ajpheart.1997.272.4.H1751.

30. Patel R, Rizvi AA. Vitamin D deficiency in patients with congestive heart failure: mechanisms, manifestations, and management. South Med J. 2011 May;104(5):325-30. https://doi. org/10.1097/SMJ.0b013e318213cf6b.

31. Pandit A, Mookadam F, Boddu S, et al. Vitamin D levels and left ventricular diastolic function. Open Heart. 2014 Feb 15;1(1):e000011. https://doi.org/10.1136/ openhrt-2013-000011.

32. Savica V, Bellinghieri G, Monardo P, Muraca U, Santoro D. An update on calcium metabolism alterations and cardiovascular risk in patients with chronic kidney disease: questions, myths and facts. J Nephrol. 2013 May-Jun;26(3):456-64. https://doi. org/10.5301/jn.5000189.

33. Santoro D, Lucisano S, Gagliostro G, et al. Vitamin D receptor polymorphism in chronic kidney disease patients with complicated cardiovascular disease. J Ren Nutr. 2015 Mar;25(2):18793. https://doi.org/10.1053/j.jrn.2014.10.022.

34. Demir M, Uyan U, Melek M. The effects of vitamin D deficiency on atrial fibrillation. Clin Appl Thromb Hemost. 2014 Jan;20(1):98-103. https://doi.org/10.1177/1076029612453762.

35. Chen WR, Liu ZY, Shi Y, et al. Relation of low vitamin $\mathrm{D}$ to nonvalvular persistent atrial fibrillation in Chinese patients. Ann Noninvasive Electrocardiol. 2014 Mar;19(2):166-73. https:// doi.org/10.1111/anec.12105.
36. Hanafy DA, Chang SL, Lu YY, et al. Electromechanical effects of 1,25-dihydroxyvitamin $\mathrm{d}$ with antiatrial fibrillation activities. J Cardiovasc Electrophysiol. 2014 Mar;25(3):31723. https://doi.org/10.1111/jce.12309.

37. Rienstra M, Cheng S, Larson MG, et al. Vitamin D status is not related to development of atrial fibrillation in the community. Am Heart J. 2011 Sep;162(3):538-41. https://doi.org/10.1016/j. ahj.2011.06.013.

38. Cerit L, Ozcem B, Cerit Z, Duygu H. Preventive Effect of Preoperative Vitamin D Supplementation on Postoperative Atrial Fibrillation. Braz J Cardiovasc Surg. 2018 Jul-Aug;33(4):347-352. https://doi.org/10.21470/1678-9741-2018-0014.

39. Nalbant A, Vatan MB, Varım P, Varım C, Kaya T, Tamer A. Does Vitamin D Deficiency Effect Heart Rate Variability in Low Cardiovascular Risk Population? Open Access Maced J Med Sci. 2017 Mar 22;5(2):197-200. https://doi.org/10.3889/ oamjms.2017.041.

40. Mangat JS, Till J, Bridges N. Hypocalcaemia mimicking long QT syndrome: case report. Eur J Pediatr. 2008 Feb;167(2):233-5. https://doi.org/10.1007/s00431-007-0438-7.

41. Fernando MP, Perera PJ, Muthukumarana OJ, Uyangoda K. Hypocalcaemia leading to supra ventricular tachycardia in a three-month old Sri Lankan infant with vitamin D deficient rickets: a case report. Ceylon Med J. 2017 Dec 26;62(4):242-43. https://doi.org/10.4038/cmj.v62i4.8576.

42. Carbone F, Mach F, Vuilleumier N, Montecucco F. Potential pathophysiological role for the vitamin $\mathrm{D}$ deficiency in essential hypertension. World J Cardiol. 2014 May 26;6(5):260-76. https://doi.org/10.4330/wjc.v6.i5.260.

43. Holló A, Clemens Z, Lakatos P. Epilepsy and vitamin D. Int J Neurosci. 2014 Jun;124(6):387-93. https://doi.org/10.3109/0 0207454.2013 .847836

44. Samaniego EA, Sheth RD. Bone consequences of epilepsy and antiepileptic medications. Semin Pediatr Neurol. 2007 Dec;14(4):196-200. https://doi.org/10.1016/j. spen.2007.08.006.

45. Sonmez FM, Donmez A, Namuslu M, Canbal M, Orun E. Vitamin D Deficiency in Children With Newly Diagnosed Idiopathic Epilepsy. J Child Neurol. 2015 Oct;30(11):1428-32. https://doi.org/10.1177/0883073814566627.

46. Aksoy A, Sönmez FM, Deger O, Hosver I, Karagüzel $\mathrm{G}$. The effects of antiepileptic drugs on the relationships between leptin levels and bone turnover in prepubertal children with epilepsy. J Pediatr Endocrinol Metab. 2011;24(9-10):703-8. https:// doi.org/10.1515/jpem.2011.019.

47. Borusiak P, Langer T, Heruth M, Karenfort M, Bettendorf $\mathrm{U}$, Jenke AC. Antiepileptic drugs and bone metabolism in children: data from 128 patients. J Child Neurol. 2013 Feb;28(2):17683. https://doi.org/10.1177/0883073812443005.

48. Fong CY, Riney CJ. Vitamin D deficiency among children with epilepsy in South Queensland. J Child Neurol. 2014 Mar;29(3):368-73. https://doi.org/10.1177/0883073812472256.

49. Khalifah RA, Hudairi A, Homyani DA, Hamad MH, Bashiri FA. Vitamin D supplementation to prevent vitamin D deficiency for children with epilepsy Randomized pragmatictrial protocol. Medicine (Baltimore). 2018 Oct;97(40):e12734. https:// doi.org/10.1097/MD.0000000000012734.

50. Christiansen C, Rodbro P, Sjo O. Anticonvulsant action" of vitamin $\mathrm{D}$ in epileptic patients? A controlled pilot study. $\mathrm{Br}$ 
Med J. 1974 May 4;2(5913):258-9. https://doi.org/10.1136/ bmj.2.5913.258.

51. Holló A, Clemens Z, Kamondi A, Lakatos P, Szücs A. Correction of vitamin D deficiency improves seizure control in epilepsy: a pilot study. Epilepsy Behav. 2012 May;24(1):131-3. https://doi.org/10.1016/j.yebeh.2012.03.011.

52. Mikati MA, Dib L, Yamout B, Sawaya R, Rahi AC, Fuleihan Gel-H. Two randomized vitamin D trials in ambulatory patients on anticonvulsants: impact on bone. Neurology. 2006 Dec 12;67(11):2005-14. https://doi.org/10.1212/01. wnl.0000247107.54562.0e.

53. Rajesh A, Mukhtyar B. Peer review and authorizationin EPEN meetingdate. In: Network EPE. 2015.
54. Gniatkowska-Nowakowska A. Fractures in epilepsy children. Seizure. 2010 Jul;19(6):324-5. https://doi.org/10.1016/j. seizure.2010.04.013.

55. Tekgul H, Dizdarer G, Demir N, Ozturk C, Tutuncuoglu S. Antiepileptic drug-induced osteopenia in ambulatory epileptic children receiving a standard vitamin D3 supplement. J Pediatr Endocrinol Metab. 2005 Jun;18(6):585-8. https://doi.org/10.1515/ jpem.2005.18.6.585.

56. Harris HW. Vitamin D deficiency and psychiatric illness. Current Psychiatry. 2013;12(4):18-27.

Received 12.06.2019

Revised 01.07.2019

Accepted 10.07.2019

\section{Information about authors}

Oksana Boyarchuk, MD, PhD, Professor, Head of the Department of pediatric diseases and pediatric surgery, State Institution of Higher Education "I. Horbachevsky Ternopil National Medical University", Ternopil, 46001, Ukraine; ORCID ID: https://orcid.org/0000-0002-1234-0040

Tetiana Kovalchuk, PhD, Associate Professor at the Department of Pediatrics 2, State Institution of Higher Education “I. Horbachevsky Ternopil National Medical University", Ternopil, 46001, Ukraine; ORCID ID: https://orcid.org/0000-0003-2455-3278

\section{Ковальчук T.А., Боярчук О.P.}

Тернопільський начіональний медичний університет імені І.я. Горбачевського МОз України, м. Тернопіль, Україна

\section{Вітамін-D-статус у пацієнтів із транзиторними втратами свідомості нетравматичного генезу (огляд літератури)}

Резюме. У статті поданий аналіз новітніх наукових досягнень із вивчення проблематики вітамін-D-статусу в пацієнтів із різними етіопатогенетичними варіантами транзиторних втрат свідомості нетравматичного генезу. Результати останніх наукових досліджень дають змогу припустити, що вітамін D може справляти опосередковану, а в деяких випадках і пряму дію в патогенезі транзиторних втрат свідомості. Дані щодо причинно-наслідкового зв'язку між низьким статусом вітаміну D і синкопальними станами є змішаними, суперечливими й неоднозначними, що великою мірою пов'язано із використанням різних доз вітаміну, його вихідною концентрацією, тривалістю терапії, генетичними відмінностями рецептора вітаміну D, різним віком, фізичними параметрами об- стежуваних, прийомом ліків, особливостями харчування 3 використанням спеціальних добавок, відмінностями у фізичній активності, особливостями клімату, порою року тощо. До сьогодні немає переконливих даних про користь застосування вітаміну D у лікуванні та профілактиці синкопе. Більшість досліджень мають спостережний характер та стосуються в основному дорослої популяції, а тому перспективним напрямком розвитку науки в цій галузі є проведення рандомізованих контрольованих досліджень 3 акцентуацією на дитяче населення.

Ключові слова: нетравматичні транзиторні втрати свідомості; рефлекторні синкопе; ортостатична гіпотензія; кардіогенні синкопе; епілепсія; психогенні синкопе; вітамін D; огляд

Ковальчук T.А., Боярчук О.P.

Тернопольский национальный медицинский университет имени И.Я. Горбачевского МЗ Украины, г. Тернополь, Украина

\section{Витамин-D-статус у пациентов с транзиторными потерями сознания нетравматического генеза (обзор литературы)}

Резюме. В статье представлен анализ новейших научных достижений по изучению проблематики витамин-D-статуса у пациентов с различными этиопатогенетическими вариантами преходящих потерь сознания нетравматического генеза. Результаты последних научных исследований позволяют предположить, что витамин D может оказывать опосредованное, а в некоторых случаях и прямое действие в патогенезе транзиторных потерь сознания. Данные о причинно-следственной связи между низким статусом витамина D и синкопальными состояниями являются смешанными, противоречивыми и неоднозначными, что во многом связано с использованием различных доз витамина, его исходной концентрацией, продолжительностью терапии, генетическими различиями рецептора витамина D, разным возрастом, физическими параметра- ми исследуемых, приемом лекарств, особенностями питания с использованием специальных добавок, различиями в физической активности, особенностями климата и временем года и др. До сих пор нет убедительных данных о пользе применения витамина D в лечении и профилактике обмороков. Большинство исследований имеют наблюдательный характер и касаются в основном взрослой популяции, поэтому перспективным направлением развития науки в этой области является проведение рандомизированных контролируемых исследований с акцентуацией на детское население.

Ключевые слова: нетравматические транзиторные потери сознания; рефлекторные синкопе; ортостатическая гипотензия; кардиогенные синкопе; эпилепсия; психогенные синкопе; витамин D; обзор 